\title{
Salingtemas Approach (Science, Environment, Technology And Society) in Biology Learning
}

\author{
HARMOKO* 1 \\ LECTURER IN BIOLOGY EDUCATION STKIP-PGRI LUBUKLINGGAU, PALEMBANG, INDONESIA
}

\begin{abstract}
SALINGTEMAS approach is a combination of STS (Science, Technology and Society) and EE (Environmental Education). In abroad, the approach is known as SALINGTEMAS (Science, Education, Technology and Society) otherwise in Indonesia, it is known as SALINGTEMAS. The main characteristic of SALINGTEMAS is learning something based on the problems and the issues faced by students in everyday life that contains components of science and technology. SALINGTEMAS tries to provide an understanding of the role of the environment on science, technology and society, and the other way. There are four phases in learning using SALINGTEMAS approach, namely: invitation phase, exploration, suggest of explanations and solutions as well as take action. In the teaching biology process, this approach is associated with the elements of environment, technology and society integratively. There are so many topics or biological problems that can be solved using SALINGTEMAS approach.
\end{abstract}

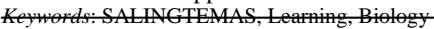

\section{INTRODUCTION}

Epoch developing and currently globalization, evoking emulation that admirably interracial and state. One of it can be seen and is measured from Human Resource quality (SDM) one that resultant. At globalization era required by man who can compete and has skill. One of effort which can be done which is via educational.

Education constitutes container to dig up potency and gets things square educative participant with skill. [1]" Education is effort realize and planned to render studying atmosphere and that learning process alae educative participant active develop her potency to have spiritual keagamaan's force, continence, personality, intelligence, noble behavior, and needful skill her, society, nation and state".

On science learning process, we just emphasize on science grasp just without link by other element which is technology, environmentally and also fused society deep SALINGTEMAS [2]

Frequent technological progress is not counterbalanced with care to environmentally so we often too meet developmental effect environment damage technological. Role learns to result scientists which can result technologies environmentally-friendly indispensable [3]

Biological subject do not despite biological material characteristic as knowledge, mengkaji's biological a variety problem which concerning with life phenomenon sort living thing on various level organisational life and interaction with environmental factor. Living thing as object of biological has alone characteristic to be appealed another science object. Biological concerning by looks for tofu and understand nature systematically. Expected biological education can be mode divide participant educating to study itself and its environment [4]

\section{RESULT AND DISCUSSION}

\subsection{MAIN IDEA}

\section{A. SALINGTEMAS Understanding}

SALINGTEMAS approach is learning approach that have main characteristic studies to fill curriculum by gets starting point of issue and problem issue that faced by participant is taught or society in day-to-day life that contain saint's component and technology. Educative participant not only study science concept but also introduce technological aspect and how that technology gets role in society [5]

[6] science approaching, technology, and effloresce beginning society on decade 70 an. Emphasis dot of this pattern is developing relationship among participant scientific knowledge is taught empirically their daily. Learning with strategy is temas each other constitute conjugate of STS'S learning strategy ( Science, Technology, and Society) and EE( Environmental Education ) 
B. SALINGTEMAS Concept and Aims

SALINGTEMAS approaching in effect will lead educative participant for thinks global and acting local and also global deep solve faced problem everyday. Problems those are on society were taken in to go to within class to be looked for its resolving utilize SALINGTEMAS approaching cohesively deep interrelationship among science elements, environmentally, technology, society [7]

Besides, science is used as constructive's activity points on day-to-day science. Therefore that idea scientific knowledge shall be not observable different of Gnostic everyday, well in form and its content, shall be emphasized [8]

Interrelationship correlation form among elements SALINGTEMAS can be seen on image 1 its following: (one that as attention focus is environmental).

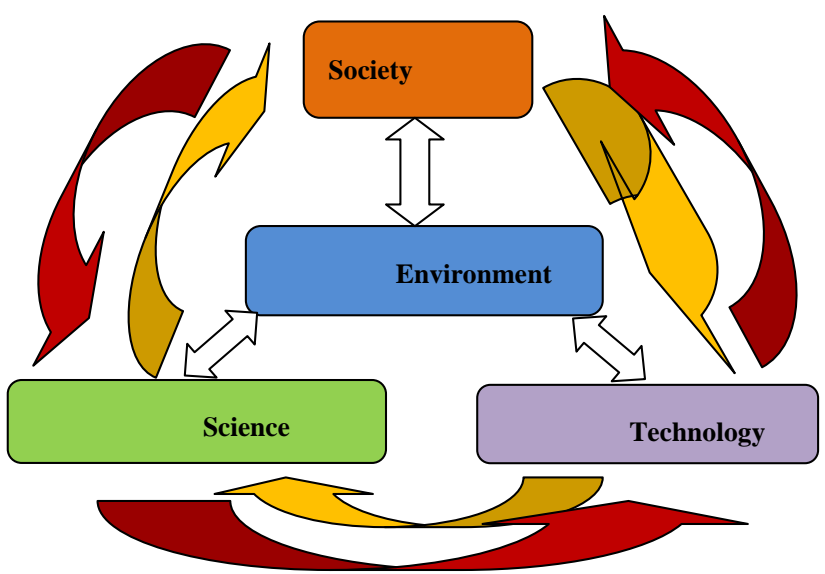

Image 1. Approaching Elements Interrelationship SALINGTEMAS

Element fourth on SALINGTEMAS Education interacts in works through a good education concept sins and also non science. For meeting participant behalf is taught needs to be created a program that corresponds to to increase participant education is taught and also society citizen.

Teachers is expected more cautious in its teaching if insert concept or topic who will be worked through by SALINGTEMAS Education tech. That topic has current and according to subject which be studied by and of course it don't go against curriculum that is standardised. One thing most importantly, Education SALINGTEMAS shall get to take in each participant teaches to get role and deep learning activity [7]

To the effect Approaching SALINGTEMAS which is to develop knowledge and technology consciousness in its exploit for knockabout life, science teaching and learning process [9]

Despitefully, to the effect approaching SALINGTEMAS divides educative participant at schooled is activate educative participant in issue resolving activity/problem already being identified that educative participant:

1) can link what does they study with what do they find dealing in day-to-day life

2) can be tested based on science and technology developing found fact and see the relevantion between technology benefit and science concepts

3) more a lot of asks and propose beyond belief question

4) identifying possible cause of what is observed and effect of thing something to what do be observed

5) perpetually have IDE / new idea

6) more hankering to what does be studie

7) more science tofu as world as physical

8) Positioning learners as a facilitator, not informer.

9) seating science as tool to solve faced problem included faced problem deep life everyday.

10) seating science process as skill applicable

11) seeing science process that shall be developed as requirement to face problems that faced

12) seeing science process as a need

169 |EDUCATION 
THE $1^{\text {st }}$ ICONLEE The First International Conference on Law, Economics and Education Muhammadiyah University of Metro, Indonesia

13) seating science as a science required just for settles about problem are not easily forget what do they study.

\section{SALINGTEMAS Characteristic}

To amount to characteristic or SALINGTEMAS approaching characteristic is aim to give ala science contextual learning. Educative participant to be taken in to situation to utilize science concept goes to form technology the favor society [10]

Severally characteristic of SALINGTEMAS approaching [11] are:

1) Regular gives science teaching.

2) Educative participant to be taken in to situation to utilize science concept goes to form technology the favor society.

3) Requested educative participant for thinks about effect possible sort that happening deep transfer process science goes to form technology.

4) Requested educative participant to word relationship between elemental sciences which is talked by other elements in SALINGTEMAS who regard relevance among elemental that if is changed deep shaped technological relationship.

5) In the context kontruktivisme participant teaches to get is asked out gets to deliberate about SALINGTEMAS of a variety starting point kind depends proprietary basic science by participant is taught pertinent.

\section{SALINGTEMAS Advantages and Disadvantages}

Learning top with SALINGTEMAS approaching than another approaching which is about how to make educative participant can do enquiry for getting science, science, environmentally, technology, and society that mutually gets bearing, so is expected gets troubleshoot that presumed arise around its life [12]. Meanwhile its terminological lacks are as follows:

1) Needed time in enough learning process long time. Remember time the limited, severally experimental material and discussion is done not fully but utilizes examples and delegation.

2) In many learning material rather difficult to dig up social issue, technology, and its environment that according to student knockabout life

3) This learning require tool facility and laboratory material that adequately fledged

\section{E. SALINGTEMAS Approaching Implementation}

[13] Interpose four activity stage braze that komprehensif's ala constitutes effort to develop student and performing grasp an associate Salingtemas project preservice learns. Stage fourth that learning is invitasi's phase or invitation or initiation, exploration, proposing explanation and solution, and taking action .

1) Invitation phase

Teacher does brainstorming and resulting severally topic possible for exploratory. Topic can get global character or local

2) Explores Phase

Teacher and student identifies about problem aught. Gathering data and information get to be gathered through questions or interview, and then analize is that information.

3) Phase proposes explanation and solution

On this phase, student manages and synthesizes information that they have developed previously in enquiry.

4) Phase takes action

Base finding that is reported in drd phase (proposing explanation and solution), student applies their finding in a few social action forms.

SALINGTEMAS implement at within class sooth doesn't need concept or process even that over unique. But, there are several principle who shall be arisen deep SALINGTEMAS approaching terminological National Science Teachers Association which is as follows:

1) Participant educating to do identification to problem and impact that is evoked around its environment

2) Utilizing local resource to look for applicable information in problem working out

3) Focuss is learning on effect that evoked by science and technology for participant is taught

4) That view grasp to more science content costs than a only can work problem

5) Mark sense emphasis to applicable process skill participant is taught to solve its own problem

6) Mark sense emphasis on consciousness gets career, particularly career which is engaged science and technology

7) Giving chance to participant educating to get experience about applicable societal life order to solve problem already being identified 
THE $1^{\text {st }}$ ICONLEE The First International Conference on Law, Economics and Education Muhammadiyah University of Metro, Indonesia

With see IPA'S characteristic SALINGTEMAS Biological and approaching as it were that is revealed at face, therefore gets to be seen that both have prospect that passably in order to increasing life skills educative participant. That SALINGTEMAS requires approaching educative participant can respond each developing at ala society scientific, it is meant that educative participant to be led to have thinking skills and at a swoop academic skills to be able to exist lives at society [14]

\section{F. SALINGTEMAS Approaching application in Processes Biological Learning.}

SALINGTEMAS approaching application in biological learning to be adjusted by participant education ladder is taught. In learning process by use of approaching SALINGTEMAS participant teaches to be asked for to link aught element squire on SALINGTEMAS.

Its explanation is as follows: correlatre educative participant among studied science concept with objects that related to the concept on other element in SALINGTEMAS, so enables participant educating to get clearer picture about that concept relevance with other element in SALINGTEMAS well in excess form and also its lack.

This following is one of approaching application example SALINGTEMAS in biological learning gets to be seen on image 2. appointed Topic which is gets bearing with adulterating environmental.

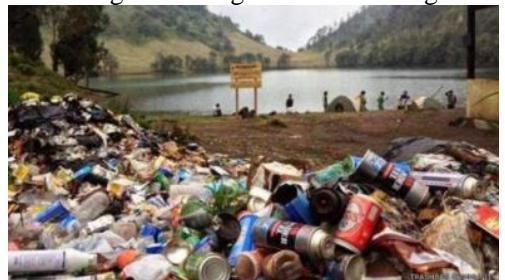

Image 2. Source Example study in SALINGTEMAS approach (Source: National Geographic in Indonesia)

Biological learning in effect is product, process, attitude and technology. On learning utilizes SALINGTEMAS approaching, requested educative participant fourth link SALINGTEMAS element with studied material, where is elements in inseparable SALINGTEMAS each other. Remembering relevance that really hand in glove among environment, technology, and society with science, therefore really been enabled to utilize relevance most conceive of our viewpoint or vision in see something. Upon same that viewpoint we put on as approaching in subject's learning science clump and also non science, notably Biological subject as a knowledge that gets direct bearing with element fourth SALINGTEMAS. Besides give opportunity to educative participant for learned kontekstual's ala, this approaching also give opportunity be developed life skills on self educative participant, so that sanagt will wheter regarding environmental approaching and SALINGTEMAS is applied in learning at schooled.

Base SALINGTEMAS approaching thinking we can build the rising generation that get knowledge towards increasing quality live each society member.

\section{CONCLUSION}

3.1 Conclusion

Base description already being presented, can be concluded that: base study, SALINGTEMAS approach in biological learning is not hard to be applied. It because of topics in biological hand in glove bearing it with environmental, technology and society.

\subsection{Recommendation}

As educator ought to do fix strategy that is utilized, and gets effort to fix learning quality and develops skill participant is taught, which is with SALINGTEMAS approaching. 


\section{REFERENCE}

[1]. Undang-Undang No 20 Tahun 2003 tentang Sistem Pendidikan Nasional

[2]. ] Nuryanto dan Binadja, A. 2010. Efektivitas Pembelajaran Kimia dengan Pendekatan SALINGTEMAS Ditinjau dari Minat dan Hasil Belajar Peserta didik.Jurnal Inovasi Pendidikan Kimia, Vol. 4, No.1, 2010, hlm 552-556.

[3]. Imaduddin, M. 2013. Modul Q-SALINGTEMAS" sebagai Rekayasa Bahan Ajar Kimia yang Bermuatan Quantum Learning dan Bervisi SALINGTEMAS. Jurnal Pendidikan Sains Universitas Muhammadiyah Semarang, Vol 01 No 01 Oktober 2013.

[4]. Arfiana, D. 2009. Profil Ketuntasan Belajar Ditinjau Dari Pendekatan Problem Based Learning (PBL) terhadap Pencapaian Kriteria Ketuntasan Minimal (KKM) Biologi Peserta didik Kelas VIIA di SMP Negeri 2 Kartasura Tahun Ajaran 2008/2009. Surakarta: Universitas Muhammadiyah Surakarta.

[5]. Rustaman, N. Y., et al. 2005. Strategi Belajar Mengajar Biologi. Common Textbook. IMSTEP JICA. Malang: UM Press.

[6]. Sumintono, B. 2008. Mengemas Sains, Teknologi, dan Masyarakatdalam Pengajaran Sekolah. Diakses pada tanggal 29 Oktober 2016 di http://deceng.wordpress.com,/

[7]. Utomo, P. 2008. Pembelajaran Fisika dengan PendekatanSALINGTEMAS. Diakses pada tanggal 29 Oktober 2016 di (http://ilmuwanmuda.wordpress.com/pmbljrn-fsk-dgn-pndktn-SALINGTEMAS/

[8]. Wasis, F.H. 2015. Pengembangan E-Book Interaktif Berbasis SALINGTEMAS (Sains, Lingkungan, Teknologi, Masyarakat) pada Materi Fluida Dinamis untuk Meningkatkan Pemahaman Konsep Peserta didik dan Penerapannya. Jurnal Inovasi Pendidikan Fisika (JIPF) Vol. 04 No. 02, Mei 2015, 69-75 ISSN: 2302-4496.

[9]. Parnayathi,I.S. 2015. Implementasi Pendekatan SALINGTEMAS dalam Model Problem Based Learning Sebagai Upaya untuk Meningkatkan Hasil Belajar IPA dan Literasi Sains-Teknologi pada Peserta didik Kelas IXC SMP Negeri 3 Banjarangkan Tahun Pelajaran 2013/2014. Jurnal Ilmiah Pendidikan (JIP) PGRI Klungkung Vol. 1, No. 1, November 2015 ISSN Nomor : 2477-3263 65.

[10]. Suriyanto dan Syaiful, R.A. 2015. Penerapan Pendekatan SALINGTEMAS untuk Meningkatkan Prestasi Belajar Kimia. Jurnal Inovasi Pendidikan Kimia, Vol 9, No. 1, 2015, hlm 1421-1430.

[11]. Binadja, A. 1999. Hakekat dan TujuanPendidikan SALINGTEMAS dalamKonteks Kehidupan dan Pendidikan yangAda. Makalah Disajikan dalam Seminar Loka Karya Pendidikan SALINGTEMAS, Kerja Sama antara SEAMEO RECSAM dan UNNES, 14-15 Desember 1999.

[12]. Paramayanti, I., dan Fitrihidayati, H. 2014. Pengembangan PerangkatPembelajaran IPA Terpadu TemaPencemaran Air denganPendekatan Sains, Lingkungan,Teknologi, dan Masyarakat(SALINGTEMAS) Kelas VII SMP,Jurnal Pendidikan Sains e-Pensa,Hal. 123-129.

[13]. Raja, K. P. 2009. Examination of the Science Technology Society with Curriculum Approach. Diakses pada tanggal 29 Oktober $2016 \mathrm{di}$ http://www.cedu.niu.edu/scie/courses/cfiles king/sts reading.htm.

[14]. Nurohman, S. 2008. Life Skills. Diakses pada Tanggal 29 Oktober 2016 di http://shobru.files.wordpress.com 